\title{
Helicobacter canis bacteraemia in a rheumatoid arthritis patient treated with tofacitinib: case report and literature review
}

\author{
Matic Mihevc ${ }^{1}$, Metka Koren Krajnc ${ }^{1}$, Maja Bombek Ihan² and Iztok Holc ${ }^{1,3^{*}}$
}

\begin{abstract}
Background: Non-Helicobacter pylori species (NHPS) are newly emerging bacteria that naturally inhabit birds and mammals apart from humans and rarely cause diseases in humans. In recent years, a rise in the number of cases associated with NHPS infections in humans has been observed. Among them, infections with Helicobacter (H.) canis are sporadic and challenging to recognise clinically. To date, ten cases of $\mathrm{H}$. canis infections in mainly immunocompromised humans have been reported in the literature. Transmission pathway is most likely zoonotic via the faecaloral route during close contacts with dogs and cats or may result from a contaminated sheep milk intake. No clear guidelines for successful antibiotic regimen are known. Important additional risk factor for infection might be biologic agents and Janus kinase inhibitors (JAKi) used in the treatment of rheumatoid arthritis (RA) and other conditions. Herein we present the first case of H. canis bacteraemia in a RA patient treated with novel JAKi tofacitinib.

Case presentation: A 65-year-old female patient with RA and rituximab-induced hypogammaglobulinemia treated with tofacitinib, methotrexate, and methylprednisolone came to a planned visit in our outpatient rheumatology clinic. She presented with a history of back pain that significantly worsened 2 days before visit. She had numbness and tingling sensation in both legs and muscle weakness. Neurological examination was within a normal range. The patient was afebrile, had no chills, and was haemodynamically stable. She was in close contact with her pet dogs. Laboratory examination showed increased markers of inflammation. She was found to have H. canis bacteraemia with underlying multilevel degenerative lumbar spinal stenosis. Identification of $H$. canis was performed by MALDI-TOF MS and $16 \mathrm{~S}$ rRNA gene sequence analysis of isolate from subcultured positive aerobic blood culture bottles. Antimicrobial susceptibility testing showed low minimum inhibitory concentrations to amoxicillin-clavulanate, cefotaxime, ceftriaxone, meropenem, and gentamicin. She was treated with combined antibiotic regimen (ceftriaxone, doxycycline) for 14 days, which resulted in total remission of the infection.

Conclusions: Clinicians should recognise $\mathrm{H}$. canis infection risk in patients with recent pet exposure and predisposing factors such as immunodeficiency disorders or diseases that demand immunosuppressive drug therapy. A minimum of two weeks of antibiotic therapy is suggested.
\end{abstract}

*Correspondence: iztok.holc@gmail.com

1 Division of Internal Medicine, Department of Rheumatology, University

Medical Centre Maribor, Ljubljanska ulica 5, 2000 Maribor, Slovenia

Full list of author information is available at the end of the article

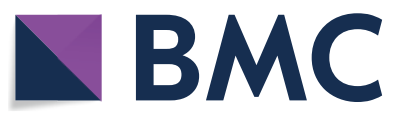

(c) The Author(s) 2021. This article is licensed under a Creative Commons Attribution 4.0 International License, which permits use, sharing, adaptation, distribution and reproduction in any medium or format, as long as you give appropriate credit to the original author(s) and the source, provide a link to the Creative Commons licence, and indicate if changes were made. The images or other third party material in this article are included in the article's Creative Commons licence, unless indicated otherwise in a credit line to the material. If material is not included in the article's Creative Commons licence and your intended use is not permitted by statutory regulation or exceeds the permitted use, you will need to obtain permission directly from the copyright holder. To view a copy of this licence, visit http://creativeco mmons.org/licenses/by/4.0/. The Creative Commons Public Domain Dedication waiver (http://creativecommons.org/publicdomain/ zero/1.0/) applies to the data made available in this article, unless otherwise stated in a credit line to the data. 
Keywords: Helicobacter canis, Zoonosis, Rheumatoid arthritis, Immunocompromised, Tofacitinib, Hypogammaglobulinemia, Treatment

\section{Background}

Helicobacter species are newly emerging Gram-negative spiral bacteria with unclear epidemiology and zoonotic transmission pathway [1]. To date, more than 35 species have been validated [2]. Generally, we classify them as Helicobacter (H.) pylori and non-Helicobacter pylori species (NHPS). H. pylori infects up to $50 \%$ of the human population and has been associated with peptic ulcers, chronic gastritis, and gastric cancer in humans [1]. Contrary, NHPS naturally inhabit birds and mammals apart from humans and rarely cause diseases in humans [1]. They have been associated with three groups of diseases: (a) gastrointestinal diseases (diarrhoea, gastric cancer), (b) bacteraemia, arthritis, cellulitis, and (c) hepatobiliary diseases (cholecystitis, hepatitis, hepatic cancer) [2-4]. In recent years, a rise in the number of NHPS infections in humans has been observed $[1,3,4]$.

Helicobacter canis is a member of the NHPS that inhabits lower intestinal as well as hepatobiliary tract of dogs and cats [5]. According to an extensive PubMed/ MEDLINE [6] search (keywords: Helicobacter canis, clinical case, infection) in April 2020, ten clinical cases of $H$. canis infection associated with human diseases have been described [5, 7-15]. An overview of clinical cases is presented in Table 1. Eight of them describe bacteraemia in patients with recent exposure to dogs or cats $[5,8-11$,

Table 1 Review of $H$. canis human infections case reports

\begin{tabular}{|c|c|c|c|c|c|c|}
\hline Author [reference] & Gender, age & $\begin{array}{l}\text { Immune system } \\
\text { competency }\end{array}$ & Pet contact & Clinical presentation & Detection & Treatment \\
\hline Burnens et al. [7] & Male, 5 years & NR & NR & Gastroenteritis & $\begin{array}{l}\text { Stool: Rotavirus, } H \text {. } \\
\text { canis }\end{array}$ & NR \\
\hline Gerrard et al. [8] & Male, 27 years & $\begin{array}{l}\text { X-linked hypogam- } \\
\text { maglobulinemia }\end{array}$ & Dog & $\begin{array}{l}\text { Recurrent fever, } \\
\text { bilateral cellulitis }\end{array}$ & $\begin{array}{l}\text { Blood culture: } H \text {. } \\
\text { canis, F. rapinni }\end{array}$ & $\begin{array}{l}\text { Doxycycline and } \\
\text { metronidazole p.o. } 5 \\
\text { months }\end{array}$ \\
\hline Leemann et al. [9] & Male, 44 years & Immunocompetent & Dog, cats & $\begin{array}{l}\text { Multifocal cellulitis, } \\
\text { subfebrile }\end{array}$ & $\begin{array}{l}\text { Blood culture: } H \text {. } \\
\text { canis }\end{array}$ & $\begin{array}{l}\text { Ceftriaxone } 2 \mathrm{~g} \text { daily i.v. } \\
2 \text { weeks }\end{array}$ \\
\hline Prag et al. [10] & Female, 7 months & Immunocompetent & Cat & $\begin{array}{l}\text { Acrocyanosis, inter- } \\
\text { mittent fever }\end{array}$ & $\begin{array}{l}\text { Blood culture: } H \text {. } \\
\text { canis }\end{array}$ & $\begin{array}{l}\text { Ampicillin and gen- } \\
\text { tamicin i.v. followed } \\
\text { by mecillinam p.o. } \\
10 \text { days }\end{array}$ \\
\hline Alon et al. [11] & Male, 78 years & $\begin{array}{l}\text { Diffuse large B } \\
\text { cell lymphoma } \\
\text { (R-CHOP) }\end{array}$ & Dogs & $\begin{array}{l}\text { Subfebrile episodes, } \\
\text { paroxysmal AF }\end{array}$ & $\begin{array}{l}\text { Blood culture: } H \text {. } \\
\text { canis }\end{array}$ & $\begin{array}{l}\text { H. pylori eradication } \\
\text { regimen }\end{array}$ \\
\hline Tankovic et al. [12] & Female, 52 years & $\begin{array}{l}\text { Crohn's disease } \\
\text { (mesalazine) }\end{array}$ & Cat & Epigastralgia & $\begin{array}{l}\text { Duodenal biopsy: } \mathrm{H} \text {. } \\
\text { canis }\end{array}$ & Not treated \\
\hline Abidi et al. [13] & Female, 57 years & $\begin{array}{l}\text { CVID, pulmonary } \\
\text { sarcoidosis (pred- } \\
\text { nisone), splenec- } \\
\text { tomy }\end{array}$ & Dogs, cats & $\begin{array}{l}\text { Recurrent fever, chills, } \\
\text { and sweats for } 3 \\
\text { months }\end{array}$ & $\begin{array}{l}\text { Blood culture: } \mathrm{H} \text {. } \\
\text { canis }\end{array}$ & $\begin{array}{l}\text { Ceftriaxone } 2 \mathrm{~g} \text { daily i.v. } \\
2 \text { weeks, doxycycline } \\
100 \text { mg p.o. } 6 \text { weeks }\end{array}$ \\
\hline $\begin{array}{l}\text { Van der Vusse } \\
\text { et al. [14] }\end{array}$ & Female, 41 years & $\begin{array}{l}\text { Kidney transplant } \\
\text { (tacrolimus, pred- } \\
\text { nisone, mycophe- } \\
\text { nolate mofetil) }\end{array}$ & Dog & Fever and cough & $\begin{array}{l}\text { Blood culture: } H \text {. } \\
\text { canis }\end{array}$ & $\begin{array}{l}\text { Cefuroxime } 1.5 \mathrm{~g} 3 \\
\text { times daily i.v. } 3 \text { days } \\
\text { followed by cipro- } \\
\text { floxacin } 500 \mathrm{mg} \text { p.o. } \\
10 \text { days }\end{array}$ \\
\hline Shakir et al. [5] & Male, 49 years & Immunocompetent & Dogs, cats & Cellulitis & $\begin{array}{l}\text { Blood culture: } H \text {. } \\
\text { canis }\end{array}$ & $\begin{array}{l}\text { One dose of vancomy- } \\
\text { cin } 1.5 \mathrm{~g} \text { i.v., doxycy- } \\
\text { cline } 100 \mathrm{mg} \text { twice } \\
\text { daily p.o. } 5 \text { days, } \\
\text { amoxicillin/clavulanic } \\
\text { acid } 500 \mathrm{mg} \text { daily p.o. } \\
8 \text { weeks }\end{array}$ \\
\hline $\begin{array}{l}\text { Gutiérrez-Arroyo } \\
\text { et al. [15] }\end{array}$ & Male, 2 months & NR & NR & $\begin{array}{l}\text { Cardiorespiratory } \\
\text { arrest }\end{array}$ & $\begin{array}{l}\text { Blood culture: } H . \\
\text { canis }\end{array}$ & Death \\
\hline
\end{tabular}


13-15]. Lately, transmission between sheep and human contact was demonstrated, recognising sheep as an additional reservoir of $H$. canis [16]. Infection of humans with $H$. canis is most likely zoonotic via the faecal-oral route during close contacts with dogs and cats or may result from a contaminated sheep milk intake $[14,16]$. Another predisposing factor might be an incompetent immune system of the host. Two previous cases described $H$. canis bacteraemia in patients with primary immunodeficiency diseases (X-linked hypogammaglobulinemia, common variable immune deficiency) $[8,13]$. Another two cases described $H$. canis bacteraemia in patients treated with immunosuppressive drugs $[11,14]$.

One class of drugs that could represent a risk factor for $H$. canis infection and that interfere with host immune system are biologic agents and Janus kinase inhibitors (JAKi) used in the treatment of rheumatoid arthritis (RA) and other conditions [17]. Kourbeti et al. have shown that biologic agents used in the treatment of RA are associated with 1.5-2-fold increased risk of opportunistic infections, especially for mycobacterial and viral infections [18]. However, no data for NHPS are available.

One of the common biologic agents used for RA management is rituximab (RTX), a B-cell depleting drug [17]. A common side effect of RTX treatment is secondary hypogammaglobulinemia which has been observed in up to $40 \%$ of patients treated with RTX [19]. It is unclear whether a reduction in immunoglobulins correlates to a higher risk of infection. Recent large cohort study, investigating RTX infection profiles, concluded that only patients with lower immunoglobulin G (IgG) levels before RTX initiation had increased risk for severe infection events within 12 months of RTX initiation [20].

On the other hand, JAKi (e.g., tofacitinib, baricitinib) are novel drugs that reversibly inhibit JAK and interfere with cytokine function and signal transduction to the nucleus via the JAK/STAT pathway [17]. Compared to patients treated with biologic agents, patients treated with JAKi have a higher risk of herpes zoster infection, whereas the risk for other infections is like one observed in patients treated with biologic agents [21].

Herein we present a case of bacteraemia caused by $H$. canis in a female RA patient treated with tofacitinib and secondary rituximab-induced IgM/IgG hypogammaglobulinemia who was in close contact with her pet dogs. To the best of our knowledge, $H$. canis infection in a patient treated with tofacitinib has not been described before.

\section{Case presentation}

A 65-year patient with seropositive RA and arterial hypertension came to a planned visit in our outpatient rheumatology clinic. She was diagnosed with RA in 1996 based on the American Rheumatism Association revised criteria for RA classification [22]. During 1996-2008, she was treated with methylprednisolone, a combination of methylprednisolone and methotrexate (MTX), and a combination of adalimumab, MTX and methylprednisolone, respectively. Between 2009 and 2018, she was treated with a combination of RTX, MTX, and methylprednisolone. However, in 2017 she noticed occasional itchy erythema on hands after RTX application. Additionally, the same year, low levels of IgM $(<0.18 \mathrm{~g} / \mathrm{L}$; reference value $0.4-2.3 \mathrm{~g} / \mathrm{L})$ and $\operatorname{IgG}(6.43 \mathrm{~g} / \mathrm{l}$; reference value $7.0-16.0 \mathrm{~g} / \mathrm{L}$ ) immunoglobulins were found. Therefore, in 2018, her treatment was changed to a combination of tofacitinib $5 \mathrm{mg}$ twice daily, MTX $10 \mathrm{mg}$ once weekly, and methylprednisolone $2 \mathrm{mg}$ every second day.

In the outpatient clinic, the patient presented with a history of back pain that significantly worsened 2 days before visit with severe pain radiating to both legs, numbness and tingling sensation in both legs, and muscle weakness. She was unstable while walking. Neurological examination was within a normal range. The patient was afebrile, had no chills, and was haemodynamically stable. Laboratory examination showed normal blood leukocyte count $\left(9.21 \times 10^{9} / \mathrm{L}\right.$; reference value $\left.4.00-10.00 \times 10^{9} / \mathrm{L}\right)$, mild neutrophilia $\left(7.88 \times 10^{9} / \mathrm{L}\right.$; reference value 1.50 $7.40 \times 10^{9} / \mathrm{L}$ ), mild anaemia (haemoglobin $116 \mathrm{~g} / \mathrm{l}$; reference value $120-150 \mathrm{~g} / \mathrm{L}$ ), increased C-reactive protein ( $98 \mathrm{mg} / \mathrm{L}$; reference value $<5 \mathrm{mg} / \mathrm{L}$ ), increased sedimentation rate $(39 \mathrm{~mm} / \mathrm{h}$; reference value $<15 \mathrm{~mm} / \mathrm{h})$, and negative procalcitonin $(0.07 \mathrm{ng} / \mathrm{mL}$; reference value $<0.5$ $\mathrm{ng} / \mathrm{mL}$ ). She was admitted to the hospital because of a suspected spondylodiscitis. Immunosuppressive therapy was discontinued. As the patient was afebrile, had no chills, no left shift leukocytosis, negative procalcitonin and there was a possibility that increased markers of inflammation reflected the baseline disease (RA), no empirical antibiotic therapy was initiated.

The first day, a chest X-ray showed no abnormalities. Magnetic resonance imaging of the lumbosacral spine revealed multilevel (L3-S1) degenerative lumbar spinal stenosis (Fig. 1). However, no signs of spondylodiscitis were found. After consultation with a neurosurgeon, there was no indication for surgical intervention.

The same day, blood samples were collected for culture. Blood was drawn in 4 blood culture bottles (two aerobic, two anaerobic). After 5 days of incubation (BACT/ALERT VIRTUO, BioMerieux), both aerobic bottles flagged positive. Gram stain showed the presence of Gram-negative spiral rods (Fig. 2). As it was difficult to establish the exact morphology of rods in Gram stain, another smear stained with Acridine Orange was performed (Fig. 3). Direct identification from bottles using Sepsityper kit and MALDI-TOF MS (Bruker Daltonik) did not yield any result. Suspecting 


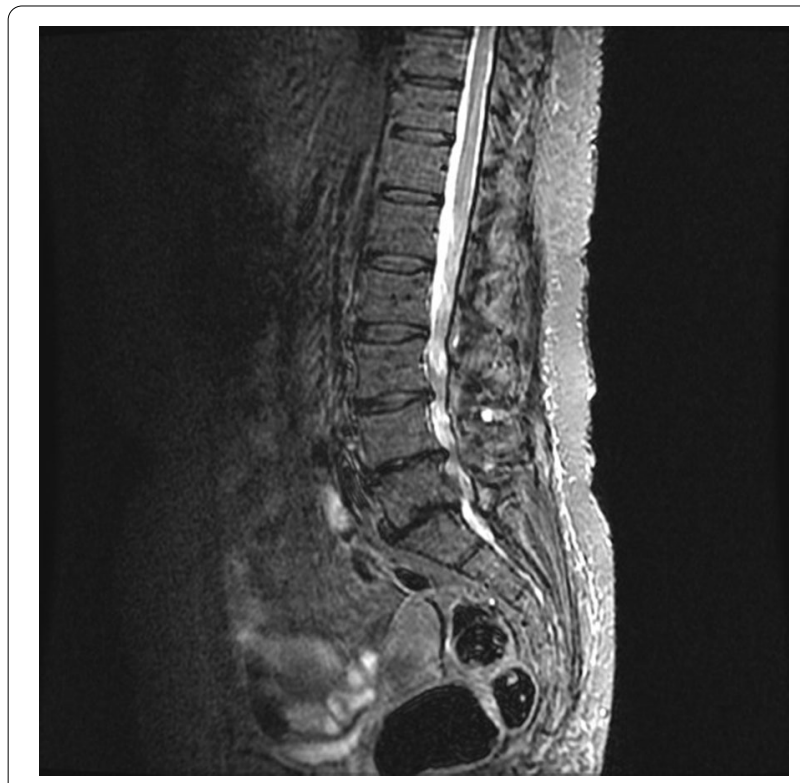

Fig. 1 Magnetic resonance imaging of the lumbosacral spine revealing multilevel (L3-S1) degenerative lumbar spinal stenosis

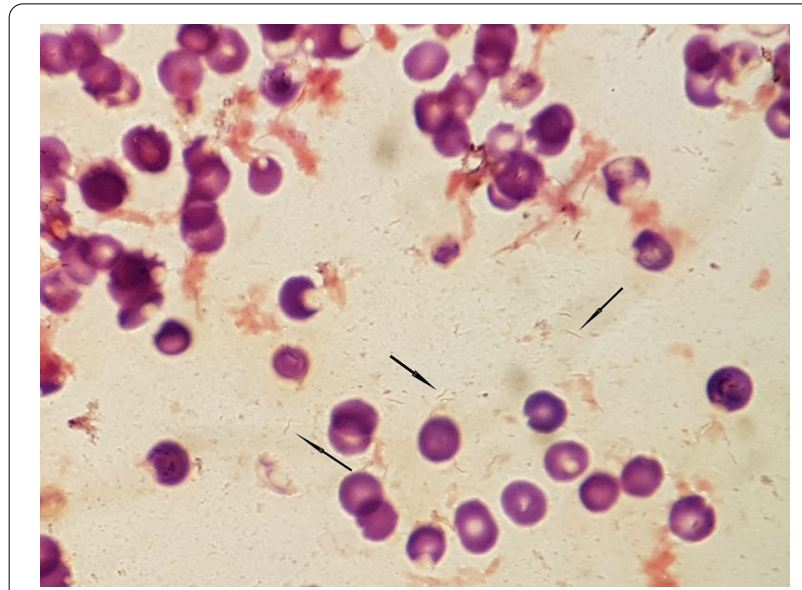

Fig. 2 Gram stain of a positive aerobic blood culture bottle. Black arrows indicate pale, thin Gram-negative spiral-shaped rods

an organism of fastidious growth after performing Gram stain, bottles were then subcultured on a set of several different media, including blood agar, Colombia agar with $5 \%$ horse blood (BioMerieux), Colombia agar with 5\% sheep blood (BioMerieux) and Brucella agar (Oxoid), all under different temperature $\left(37\right.$ and $\left.42{ }^{\circ} \mathrm{C}\right)$ and atmosphere conditions, including aerobic with $5 \% \mathrm{CO}_{2}$ and microaerophilic atmosphere. After $48 \mathrm{~h}$, the only media with visible growth, though extremely scant, was Colombia sheep agar incubated in microaerophilic atmosphere at $37^{\circ} \mathrm{C}$. After $72-96 \mathrm{~h}$, growth

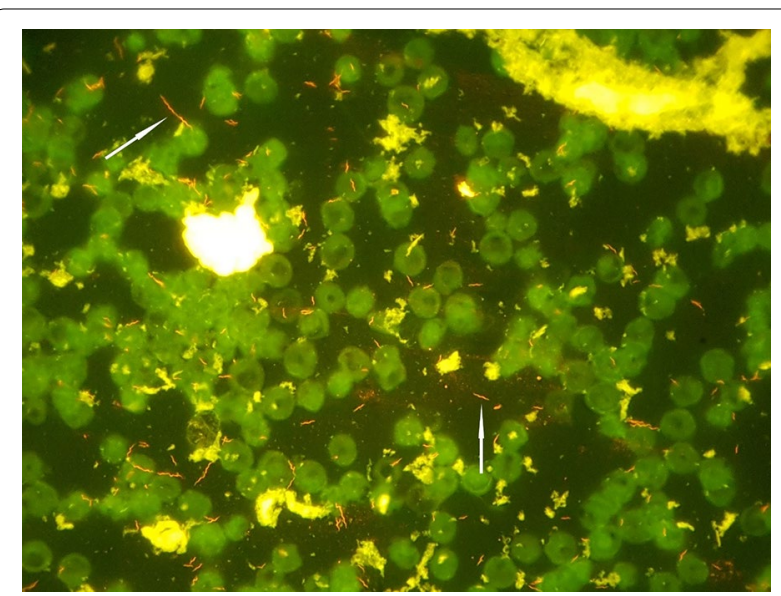

Fig. 3 Acridine orange stain of a positive aerobic blood culture bottle. White arrows indicate spiral-shaped rods

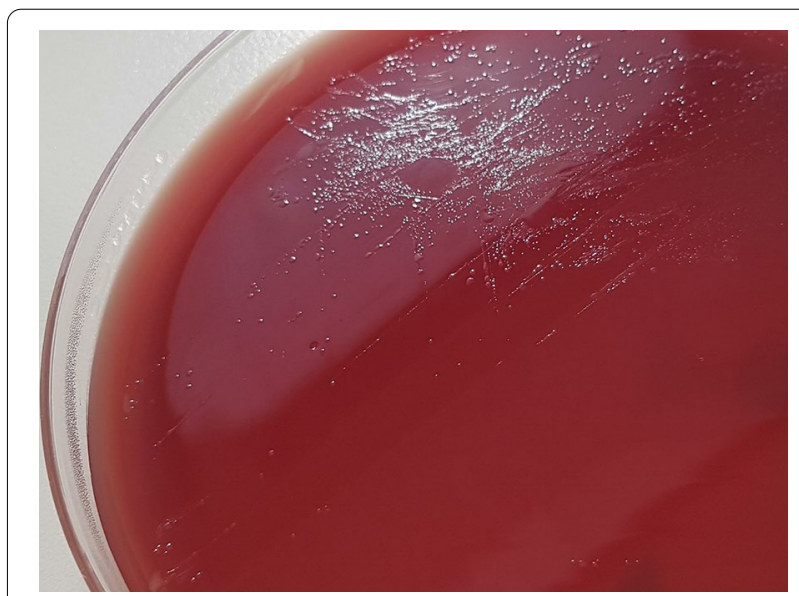

Fig. 4 Brucella agar plate after 3 days of incubation at $37^{\circ} \mathrm{C}$ in microaerophilic conditions showing translucent round or irregularly shaped colonies

was observed on all media incubated in microaerophilic conditions, at $37^{\circ} \mathrm{C}$ as well as $42{ }^{\circ} \mathrm{C}$, although the growth was better at $37^{\circ} \mathrm{C}$. Shiny translucent colonies of round or irregular shape were best observed on Brucella agar (Fig. 4). After 6 days of incubation, a phenomenon of swarming was observed on Colombia sheep agar, incubated in microaerophilic conditions at $37{ }^{\circ} \mathrm{C}$ (Fig. 5). The result of identification by MALDITOF MS from culture was $H$. canis. However, score was insufficient for reliable result (1.88).

Additionally, $16 \mathrm{~S}$ rRNA sequence analysis of isolate was performed. DNA from pure culture was extracted with Chelex 100 Resin (BioRad). Amplification of the full $(1,5 \mathrm{~kb}) 16 \mathrm{~S}$ rRNA gene was performed as described previously by Bianciotto et al. [23]. Amplified 


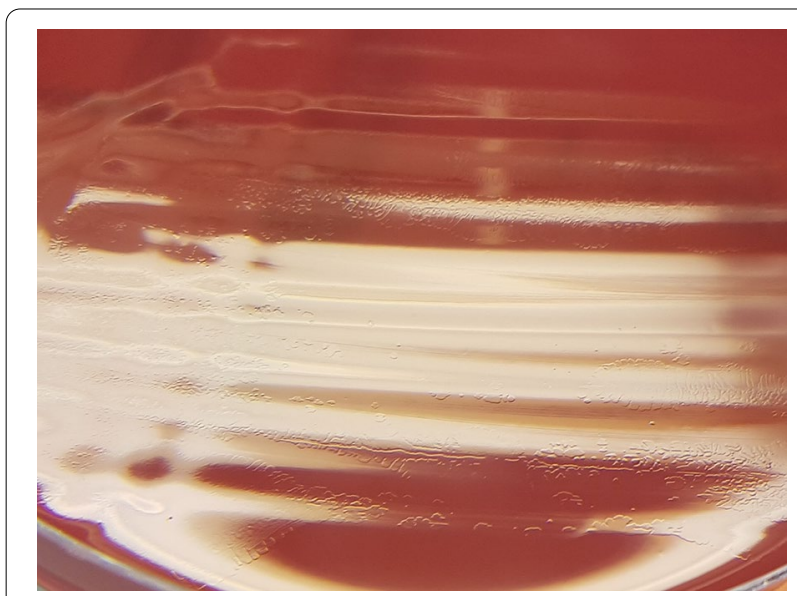

Fig. 5 Colombia sheep agar plate after 6 days of incubation at $37^{\circ} \mathrm{C}$ in microaerophilic conditions showing swarming phenomenon

$16 \mathrm{~S}$ rDNA were sequenced on 3500 Genetic Analyzer using the BigDye Terminator Kit (Applied Biosystems). The forward and reverse strands were aligned using BioNumerics v7.5 (Applied Maths) and the $16 \mathrm{~S}$ rDNA sequence was then compared with entries in MicrobeNet (https://www.cdc.gov/microbenet/index.html).

The $16 \mathrm{~S}$ rRNA sequence analysis confirmed identification of $H$. canis previously obtained with MALDI-TOF MS. Antimicrobial susceptibility testing, performed with gradient E-test MIC method (ETEST - BioMerieux), showed low minimum inhibitory concentrations (MICs) to amoxicillin-clavulanate, cefotaxime, ceftriaxone, meropenem, and gentamicin (Table 2).

On the 9th day, after $H$. canis infection identification, combined antibiotic regimen with ceftriaxone 2 g daily intravenously and doxycycline $100 \mathrm{mg}$ twice daily perorally for 14 days was initiated. The antibiotic regimen was chosen according to previous case reports $[5,13]$. Five days after combined antibiotic treatment initiation, markers of inflammation decreased (leukocyte blood count $5.31 \times 10^{9} / \mathrm{L}, \mathrm{C}$-reactive protein $\left.11 \mathrm{mg} / \mathrm{L}\right)$.

In between, due to anaemia and increased markers of inflammation, other foci of inflammation or malignancy were investigated [24]. However, none were found. Ultrasound of the abdomen revealed gallstones. Esophagogastroduodenoscopy showed chronic superficial gastritis. Ultrasound of the heart showed no significant abnormalities. Additionally, serology testing for Borrelia burgdorferi, Leptospira spp., and stool culture (Salmonella spp., Shigella spp., Campylobacter spp., Yersinia spp., E. coli O157, Shiga toxin-producing E. coli) were negative.

Before discharge, blood samples for control blood cultures were collected. All were sterile. Furthermore, primary sterile samples were tested for $16 \mathrm{~S}$ rRNA gene sequencing. All samples were negative for $16 \mathrm{~S}$ rRNA gene of Helicobacter species at discharge.

\section{Discussion and conclusions}

In this case report, we described a female patient with bacteraemia caused by $H$. canis and RA treated with tofacitinib in combination therapy. Infection occurred 8 months after treatment initiation. According to previous case reports (Table 1), clinical presentation of $H$. canis bacteraemia is diverse. Three case reports described multifocal cellulitis with or without fever episodes $[5,8$, 9]. Four others described intermittent and/or recurrent fever only $[10,11,13,14]$. One case in an infant ended with a cardiorespiratory arrest [15]. Our case described a patient with lumboischialgia that resulted from multilevel degenerative lumbar spinal stenosis. Apart from increased markers of inflammation and clinical presentation of spinal stenosis, our patient had asymptomatic $H$. canis bacteraemia. We present the first case describing laboratory findings of $H$. canis bacteraemia only. However, our patient received chronic non-steroidal anti-inflammatory drug and paracetamol therapy which could mask febrile episodes frequently presented in other patients [25].

Important risk factor for $H$. canis bacteraemia might be an incompetent immune system. Majority of previous patients with bacteraemia were immunocompromised. One case described bacteraemia in a patient with $\mathrm{X}$-linked hypogammaglobulinemia [8]. Another case described a patient with common variable immune deficiency, sarcoidosis, and splenectomy [13]. Furthermore, two case reports described patients receiving immunosuppressive drugs. The first case described a patient with B cell lymphoma treated with R-CHOP chemotherapy [11]. The second case described a kidney transplant patient treated with tacrolimus, mycophenolate mofetil, and prednisone [14]. Our patient had a combination of both risk factors.

On the one hand, she had RTX-induced hypogammaglobulinemia. On the other hand, she was treated

Table 2 Results of antimicrobial susceptibility testing of $H$. canis isolated strain

\begin{tabular}{lllll}
\hline Antimicrobial substance & Amoxicillin-clavulanate & Cefotaxime & Ceftriaxone & Gentamicin \\
\hline MIC $[\mu \mathrm{g} / \mathrm{mL}]$ & 0.016 & 0.125 & 0.25 & 0.25 \\
\hline
\end{tabular}

MIC minimum inhibitory concentration 
with tofacitinib, MTX, and a low methylprednisolone dose. A recent large cohort study found that patients with RA, receiving tofacitinib in combination with MTX, have had $3.0 \%$ risk of severe infections, among them, $0.2 \%$ risk for tuberculosis (TBC), $4.1 \%$ risk for herpes zoster, and $0.6 \%$ risk for opportunistic infections excluding TBC [26]. The risk of serious infections was higher in patients older than 65 years [26].

Another factor contributing to a low number of $H$. canis case reports might be challenging and easily overlooked laboratory recognition. $H$. canis can grow in standard aerobic blood cultures, however, in general, micro-aerophilic atmosphere conditions $\left(37\right.$ or $42{ }^{\circ} \mathrm{C}$ ) are needed for growth [5]. Furthermore, it is relatively inert biochemically - catalase, urease, and nitrate negative [13]. Until recently, identifying fastidious organisms like NHPS was challenging in most clinical laboratory settings. Because of their low biochemical reactivities, differentiation methods relying on isolates' biochemical characteristics were unsuccessful. With the development and implementation of newer identification methods like MALDI-TOF MS and molecular methods like $16 \mathrm{~S}$ rRNA gene sequence analysis, accurate identification of these fastidious microorganisms became readily available $[5,13,27]$.

Currently, no recommendations for treatment of H. canis bacteraemia are available. Previous case reports described different treatment regimens. Some patients were treated with amoxicillin-clavulanate [5] or ceftriaxone [9], whereas others were treated with a combination of ceftriaxone and doxycycline [13] or a combination of cefuroxime and ciprofloxacin [14]. A minimum of 2 weeks and a maximum of 8 weeks of therapy were described. We successfully treated our patient with a combination of ceftriaxone and doxycycline in a duration of 14 days. To point out, this is the third case where results of in vitro antimicrobial susceptibility testing are presented. Like our results, Leeman et al. found susceptibility of $H$. canis to amoxicillin, amoxicillin-clavulanate, ceftriaxone, piperacillin-tazobactam, imipenem, metronidazole, and clindamycin [9]. Other study found susceptibility to nalidixic acid only [10]. Clear recommendations for optimal antibiotic treatment regimen of $H$. canis infections cannot be made. However, this is the fifth case where either a third-generation cephalosporin or doxycycline was used and resulted in complete remission of H. canis infection $[8,9,13,14]$.

In conclusion, $H$. canis infections are rare and difficult to diagnose. Clinicians should recognise risk for infection in patients with recent exposure to dogs, cats or sheep while not improving with standard therapy. Risk further increases with underlying comorbidities, especially, autoimmune diseases, immunodeficiency disorders, or use of immunosuppressive agents. A minimum of 2 weeks of therapy is suggested [13].

\section{Abbreviations}

CVID: Common variable immune deficiency; $H$. canis: Helicobacter canis; $H$. pylori: Helicobacter pylori; IgG: Immunoglobulin G; IgM: Immunoglobulin M; JAKi: Janus kinase inhibitors; MALDI-TOF MS: Matrix-assisted laser desorption/ ionisation-time of flight mass spectrometry; MTX: Methotrexate; NHPS: NonHelicobacter pylori species; RA: Rheumatoid arthritis; R-CHOP: Rituximab -cyclophosphamide, hydroxydaunorubicin, oncovin, prednisone; rRNA: Ribosomal ribonucleic acid; RTX: Rituximab; MIC: Minimum inhibitory concentration.

\section{Authors' contributionss}

IH recognised clinical case and managed the patient. MM took the lead in writing the manuscript. All authors read and approved the final manuscript.

Funding

The authors have no sources of funding to declare.

\section{Availability of data and materials}

The datasets are available from the corresponding author on reasonable request.

\section{Declarations}

Ethics approval and consent to participate

Not applicable.

\section{Consent for publication}

Written informed consent for publication of their clinical details and/or clinical images was obtained from the patient. A copy of the consent form is available for review by the Editor of this journal.

\section{Competing interests}

The authors have none to declare.

\section{Author details}

${ }^{1}$ Division of Internal Medicine, Department of Rheumatology, University Medical Centre Maribor, Ljubljanska ulica 5, 2000 Maribor, Slovenia. ${ }^{2}$ National Laboratory for Health, Environment and Food, Maribor, Slovenia. ${ }^{3}$ Faculty of Medicine, Department of Internal Medicine, University of Maribor, Maribor, Slovenia.

Received: 28 April 2020 Accepted: 17 March 2021

Published online: 08 April 2021

\section{References}

1. Mladenova-Hristova I, Grekova O, Patel A. Zoonotic potential of Helicobac ter spp. J Microbiol Immunol Infect. 2017;50(3):265-9. https://doi.org/10. 1016/j.jmii.2016.11.003.

2. Péré-Védrenne C, Flahou B, Loke MF, Ménard A, Vadivelu J. Other Helicobacters, gastric and gut microbiota. Helicobacter. 2017;22(Suppl1):e12407. https://doi.org/10.1111/hel.12407.

3. Fox JG. The non-H pylori helicobacters: their expanding role in gastrointestinal and systemic diseases. Gut. 2002;50(2):273-83. https://doi.org/10. 1136/gut.50.2.273.

4. Ménard A, Smet A. Review: other Helicobacter species. Helicobacter. 2019. https://doi.org/10.1111/hel.12645.

5. Shakir SM, Powers-Fletcher MV, Slechta ES, Fisher MA. Helicobacter canis bacteraemia and cellulitis in a patient with end-stage renal disease. JMM Case Rep. 2017;4(11):e005126. https://doi.org/10.1099/jmmcr.0.005126.

6. U.S. National Institutes of Health, National Library of Medicine. Assessed 10 April 2020. http://www.ncbi.nlm.nih.gov/pubmed/. 
7. Burnens AP, Stanley J, Schaad UB, Nicolet J. Novel Campylobacter-like organism resembling Helicobacter fennelliae isolated from a boy with gastroenteritis and from dogs. J Clin Microbiol. 1993;31(7):1916-7.

8. Gerrard J, Alfredson D, Smith I. Recurrent bacteremia and multifocal lower limb cellulitis due to Helicobacter-like organisms in a patient with X-linked hypogammaglobulinemia. Clin Infect Dis. 2001;33(10):E116-8. https://doi.org/10.1086/323405.

9. Leemann C, Gambillara E, Prod'hom G, Jaton K, Panizzon R, Bille J, et al First case of bacteremia and multifocal cellulitis due to Helicobacter canis in an immunocompetent patient. J Clin Microbiol. 2006;44(12):4598-600. https://doi.org/10.1128/jcm.01453-06.

10. Prag J, Blom J, Krogfelt KA. Helicobacter canis bacteraemia in a 7-monthold child. FEMS Immunol Med Microbiol. 2007;50(2):264-7. https://doi. org/10.1111/j.1574-695X.2007.00271.X.

11. Alon D, Paitan Y, Ben-Nissan Y, Chowers M. Persistent Helicobacter canis bacteremia in a patient with gastric lymphoma. Infection. 2010;38(1):624. https://doi.org/10.1007/s15010-009-9067-6.

12. Tankovic J, Smati M, Lamarque D, Delchier JC. First detection of Helicobacter canis in chronic duodenal ulcerations from a patient with Crohn's disease. Inflamm Bowel Dis. 2011;17(8):1830-1. https://doi.org/10.1002/ ibd.21610.

13. Abidi MZ, Wilhelm MP, Neff JL, Hughes JG, Cunningham SA, Patel R. Helicobacter canis bacteremia in a patient with fever of unknown origin. J Clin Microbiol. 2013;51(3):1046-8. https://doi.org/10.1128/JCM.02548-12.

14. Van der Vusse ML, van Son WJ, Ott A, Manson W. Helicobacter canis bacteremia in a renal transplant patient. Transpl Infect Dis. 2014;16(1):125-9. https://doi.org/10.1111/tid.12174.

15. Gutiérrez-Arroyo A, Falces-Romero I, Corcuera-Pindado M, RomeroGómez MP. Bacteraemia in a two month-old infant. Enferm Infecc Microbiol Clin. 2017;35:676-7. https://doi.org/10.1016/j.eimce.2017.11.012.

16. Sabry MA, Abdel-Moein KA, Seleem A. Evidence of zoonotic transmission of Helicobacter canis between sheep and human contacts. Vector Borne Zoonotic Dis. 2016;16(10):650-3. https://doi.org/10.1089/vbz.2016.1994.

17. Kotyla PJ. Are janus kinase inhibitors superior over classic biologic agents in RA patients? BioMed Res Int. 2018;2018:7492904. https://doi.org/10. 1155/2018/7492904.

18. Kourbeti IS, Ziakas PD, Mylonakis E. Biologic therapies in rheumatoid arthritis and the risk of opportunistic infections: a meta-analysis. Clin Infect Dis. 2014;58(12):1649-57. https://doi.org/10.1093/cid/ciu185.

19. Casulo C, Maragulia J, Zelenetz AD. Incidence of hypogammaglobulinemia in patients receiving rituximab and the use of intravenous immunoglobulin for recurrent infections. Clin Lymphoma Myeloma Leuk. 2013;13(2):106-11. https://doi.org/10.1016/j.clml.2012.11.011.

20. Md Yusof MY, Vital EM, McElvenny DM, Hensor EMA, Das S, Dass S, et al. Predicting severe infection and effects of hypogammaglobulinemia during therapy with rituximab in rheumatic and musculoskeletal diseases. Arthritis Rheumatol. 2019;71(11):1812-23. https://doi.org/10.1002/art. 40937.

21. Harigai M. Growing evidence of the safety of JAK inhibitors in patients with rheumatoid arthritis. Rheumatology. 2019;58(Suppl1):i34-42. https:// doi.org/10.1093/rheumatology/key287.

22. Arnett FC, Edworthy SM, Bloch DA, McShane DJ, Fries JF, Cooper NS, et al. The American Rheumatism Association 1987 revised criteria for the classification of rheumatoid arthritis. Arthritis Rheum. 1988;31(3):315-24. https://doi.org/10.1002/art.1780310302.

23. Bianciotto V, Bandi C, Minerdi D, Sironi M, Tichy HV, Bonfante P. An obligately endosymbiotic mycorrhizal fungus itself harbors obligately intracellular bacteria. Appl Environ Microbiol. 1996;62(8):3005-10. https:// doi.org/10.1128/AEM.62.8.3005-3010.1996.

24. Bitik B, Mercan R, Tufan A, Tezcan E, Küçük H, Illhan M, et al. Differential diagnosis of elevated erythrocyte sedimentation rate and C-reactive protein levels: a rheumatology perspective. Eur J Rheumatol. 2015;2(4):1314. https://doi.org/10.5152/eurjrheum.2015.0113.

25. Ludwig J, McWhinnie H. Antipyretic drugs in patients with fever and infection: literature review. Br J Nurs. 2019;28(10):610-8. https://doi.org/ 10.12968/bjon.2019.28.10.610.

26. Wollenhaupt J, Lee E-B, Curtis JR, Silverfield J, Terry K, Soma K, et al. Safety and efficacy of tofacitinib for up to 9.5 years in the treatment of rheumatoid arthritis: final results of a global, open-label, long-term extension study. Arthritis Res Ther. 2019;21(1):89. https://doi.org/10.1186/ s13075-019-1866-2

27. Wieser A, Schneider L, Jung J, Schubert S. MALDI-TOF MS in microbiological diagnostics-identification of microorganisms and beyond (mini review). Appl Microbiol Biotechnol. 2012;93(3):965-74. https://doi.org/10. 1007/s00253-011-3783-4.

\section{Publisher's note}

Springer Nature remains neutral with regard to jurisdictional claims in published maps and institutional affiliations.
Ready to submit your research? Choose BMC and benefit from:

- fast, convenient online submission

- thorough peer review by experienced researchers in your field

- rapid publication on acceptance

- support for research data, including large and complex data types

- gold Open Access which fosters wider collaboration and increased citations

- maximum visibility for your research: over 100M website views per year

At $B M C$, research is always in progress.

Learn more biomedcentral.com/submissions 